\title{
The Amphinomidæ, Aphroditidæ, Polynoidæ, and Sigalionidæ of Plymouth and the English Channel.
}

By

T. V. Hodgson.

Having attempted to investigate the Polychrte fauna of the Plymouth district during those favourable opportunities which have occurred during the past three years, I now put upon record some few notes respecting a small section of this interesting but extremely perplexing group.

The section under consideration is that treated of by McIntosh in his recently published Monograph (20). I have taken advantage of that work to compile a synoptical table of the British species belonging to those genera which are represented in the English Channel.

The attention that I have been able to give to these Polychætes has not been what I could have wished, nor has it been anything like adequate to exhaust the local species. I might therefore publish a very incomplete list, or, by bringing into a compact form the records of those species known to occur in the Channel in addition to a synoptical table, I might be able to assist some future worker. I have adopted the latter alternative. The synopsis has been difficult to prepare, and that difficulty has not been diminished by a complete ignorance of many of the species included. Many are known only from single or even mutilated specimens which have been obtained from the stomachs of fishes.

One is rarely satisfied with definitions, generic or specific, and this dissatisfaction becomes the more pronounced when comparisons have to be made. In adopting the classification of McIntosh an awkward situation presents itself. The genus Polynoë, after undergoing numerous fluctuations, has, for the time at least, been divided into a number of small but closely related genera. There are nine of these included in the British fauna, distinguished by the possession of fifteen elytra. De St. Joseph, in his Annélides Polychètes des côtes de Dinard, unites four of these genera with others; thus Harmothoë, Eunoa, Evarne, and Antinoë are included in the single genus Harmothoë. I have allowed the four new species described by that author to remain in the genus Harmothoë without attempting to reduce them to the smaller genera of McIntosh, it being, in a paper of this kind, a matter of small 
importance. In dividing the genus Harmothoë into three sections, I have relied largely upon the accuracy of McIntosh's drawings.

In the following synopsis the family and generic descriptions are copied from McIntosh (20), with a slight alteration of terminology and omission of all points relating to internal anatomy.

The local area included in the scope of this paper is the entire south coast of Devon and Cornwall. The field thus defined is a large one, and has not by any means been exhaustively worked. The central area in the immediate vicinity of Plymouth is best known, and as the operations of the Marine Biological Association extend east and west, so the more likely and productive spots will be first visited, and the intervening areas will receive attention in due course. The varied character of the shores round Plymouth renders it a particularly rich spot for Polychætes. Extensive mud-flats occur in all the rivers, and the shore in the Sound possesses numerous areas strewn with fucoidcovered boulders and stones, with or without muddy sand, in large patches. These form productive grounds for numerous species, the richest and best of which are Drake's Island, Rum Bay, the Bridge, and Bovisand Bay.

Below tidal water Millbay Channel is, perhaps, the richest field. The bottom there is covered with stones of varied character, rough and smooth, usually bored by Saxicava and other boring animals. These form the home of numerous hydroids, sponges, etc.

Queen's Ground and Duke Rock are cleaner and yield irregular clinkers from the ocean steamers, with shell detritus, all of which are more or less covered with hydroids, polyzoa, and algæ, etc.

Outside the Sound, Wembury Bay is a favourite ground, and exhibits every phase, from huge fucoid-covered boulders, stones, to muddy sand and fine sand; and though its area is not particularly large, its varied character renders it exceptionally productive.

The varied character of the bottom offshore has been indicated in a remarkably precise manner by Allen, in his paper "On the Fauna and Bottom-Deposits near the Thirty-Fathom Line from the Eddystone Grounds to Start Point."

The fauna of Salcombe Harbour has recently been investigated by Mr. Allen and Mr. Todd with interesting results as regards Polychætes, and I am indebted to them for the opportunity of including those species here, and further to the latter gentleman for giving me other notes, which are distinguished by his initials.

Throughout the paper I have marked with an asterisk (*) all those species which are known to occur in the local area as already defined. All those forms occurring elsewhere in the Channel are distinguished by a dagger ( $\dagger)$. 
Amphinomid e.

\section{FAMILIES.}

Body elongate, or more or less ovoid.

Parapodia much modified, the neuro and notopodia widely separated, the latter merged in the dorsum and provided with chætæ, branchiæ, and cirri.

APHRODITID \&.

Body comparatively large, ovate or oblong.

Chætæ very strong. Parapodia bearing fifteen elytra, which are sometimes concealed by a dense felt.

\section{PolynoId e.}

Body more or less elongate, usually comparatively broad, more or less concealed by a variable number of elytra.

Prostomium, with four sessile eyes and three tentacles.

\section{ACOETIDE.}

Body elongate, partially concealed by numerous elytra.

Prostomium, with pedunculate eyes and three tentacles.

\section{SIGALIONID $\pi$.}

Body elongate, concealed by numerous elytra, which are accompanied by a cirriform gill. Ctenidia on all parapodia.

\section{FAMILY AMPHINOIMIDA.}

Prostomium rounded or compressed. A median and two lateral tentacles, though the latter may be absent, an elongated dorsal caruncle, and four eyes.

Body elongate, oblong or ovate oblong, feet with the noto and neuropodia widely separated and furnished with cirri.

Mouth removed from the tip of the snout ventrally, with modified segments laterally; protrusible proboscis devoid of jaws.

Parapodia peculiarly modified, the notopodium being extended and merged into the dorsum, but with chætæ, branchiæ, and cirri. Chætæ brittle, calcareous, and tubular, with gelatinous contents; rarely hook-like spines.

Buccal apparatus and proboscis large and complex.

Anus dorsal, with two posterior appendages.

Sub-FAMILY I. AMPHINOMINA.

Body elongate. A median and two lateral tentacles. Noto and neuropodia widely separated.

\section{Genus Paramphinome.}

Prostomium small. No caruncle, no eyes. Five tentacles.

Branchiæ on anterior segments only. 
Genus Eurythö̈.

Prostomium large. A caruncle, four eyes, dorsal. A median and two lateral tentacles.

Branchiæ from the third segment backward.

Sub-FAMily II. EUPHROSYNINA.

Body oblong or ovate oblong: A median tentacle, a trilobed caruncle.

Genus Spinther.

Prostomium merged into general contour of body. Eyes four, at base of tentacle.

No branchiæ.

\section{Genus Euphrosyne.}

Prostomium narrow. Eyes four, two dorsal and two ventral.

Notopodium merged into the dorsum and provided with several arborescent branchiæ, and two or three dorsal cirri on each side.

Genus EURYTHOË, Kinberg.

Body elongated, with flattened rectangular segments.

Prostomium large, rounded or pentagonal. Eyes four, dorsal. A median and two lateral tentacles. Caruncle trilobed.

Palpi forming two adnate lobes inferiorly in front of the mouth, each with a tentacular process or stylode.

Dorsal cirrus single. Chætæ of the notopodium linear, subarticulate; others sub-bifid, with a serrate limb and a short process. Neuropodial chætæ bifid.

Branchiæ from the third segment backward.

†EURYthö̈ Borealis, Sars.

\section{Genus EUPHROSYNE, Savigny.}

Body generally short, oblong, equally narrowed at either end. Segments not numerous, two thick styles posteriorly.

Prostomium narrow, frontal part narrowest, a band passing downward to the inferior ridge. Eyes both on the dorsal and ventral surfaces. One median tentacle situated in front of eyes. Lateral tentacles two, very short, springing in front of the inferior eyes.

Fascicles of chætæ arranged on each side of the segments. Notopodial chætæ forming a transverse row, no barbs. Neuropodial chætæ grouped in a broad pencil. Capillary chætæ unequally bifurcate. Dorsal cirri two (or three, Ehlers) on each side, one at the inner border of the fascicle, the other at the outer margin. Ventral cirri single. 
Branchiæ dorsal, in rows, and more or less ramose.

Palpi forming fixed lobes on each side of the mouth.

Mouth opening on the ventral surface and extending over several segments.

Buccal apparatus complex.

*E. Foliosa, $A u d$. et $E d w$. Size nearly 1 inch.

Branchiæ with ovate expansions at the tips.

E. ARMadillo, Sars. Size $\frac{1}{3}$ inch.

Branchiæ with lanceolate tips.

E. Robertsoni, McIntosh. Size $\frac{1}{2}$ inch.

Branchiæ with digitate tips, only a trace of a swelling.

+E. INTERMedia, St. Joseph.

As $E$. foliosa, with a bundle of chætæ between noto and neuropodia.

\section{FAMILY APHRODITID尼.}

Annelids of an ovate or oblong form, convex dorsally, with a distinct prostomium, on which are a pair of eyes and a median tentacle, and under which is a papillose facial tubercle.

No lateral tentacles, two palpi. Tentacular cirri long, buccal cirri (ventral cirri of the second foot) moderately long.

Proboscis long and powerful, with four muscular ridges representing teeth, and a tough internal lining.

Dorsal fimbriæ small, alternating with the elytra, or absent.

First foot bearing three dense tufts of bristles.

Elytra, fifteen pairs occurring on segments $2,4,5,7,9, \ldots 25,28,31$.

Segmental organs (nephridia) opening by well-marked papillæ pointing upwards between the feet.

Aphrodita, Linn.

Elytra concealed by a close felt of simple hairs.

Eyes sessile. All chætæ simple.

LATMatonice, Kinberg.

Elytra concealed by a close felt of simple hairs.

Eyes on short peduncles.

Chætæ of the elytra-bearing feet glochidiate.

Hermione, Blainville.

No dorsal felt. Eyes pedunculate.

Elytra alternating with dorsal cirri.

Chætæ simple, glochidiate, and bidentate. 


\section{Genus APHRODITA, Linnceus.}

Eyes sessile.

Dorsum covered with a thick, close felt of massive, simple hair. Chætæ of the neuropodium long, silky, and iridescent, and like all other chætæ, simple, not barbed or toothed.

*Aphrodita aculeata, Linn.

\section{Genus +Latmatonice, Kinberg.}

Eyes on short peduncles placed near the anterior border of the head.

Dorsum covered with felt.

Spines of the elytra-bearing feet glochidiate, other segments with lateral bundles of stout bristles and a tuft of hair-like chætæ. Chætæ of the neuropodium semi-pinnate.

Segmental organs (nephridia) opening externally by papillæ directed upwards between the parapodia.

$\dagger$ L. FILICornis, Kinberg.

Prostomium tripartite.

Glochidiate chætæ with three or four teeth.

L. PRODUCTA, var. Britannica, McIntosh.

Prostomium triangular. Ocular peduncles present, but no eyes.

No dorsal felt. $\ddagger$

Glochidiate chætæ with four recurved fangs, besides the process at the base of the terminal spear-tip.

\section{Genus HERMIONE, Blainville.}

Prostomium, with a single tentacle and two palps.

Peristomium bears chætæ and two long cirri.

Pedunculated eyes fixed to the margin of the prostomium.

Maxillæ absent or small.

No dorsal felt. Elytra alternating with dorsal cirri.

Neuro and notopodial divisions of the feet distinct.

Elytra-bearing feet with glochidiate dorsal spines and a tuft of strong chætæ over the elytra. Neuropodial chætæ bidentate.

Segmental papillæ from the eighth to the twenty-ninth foot.

*Hermione hystrix, Savigny. Size to $2 \frac{1}{4}$ inches.

\section{FAMILY POLYNOID压.}

Body more or less elongate.

No facial tubercle, convex prostomium; the base of the tentacle arising from the middle anteriorly. Two lateral tentacles, four eyes, palpi elongate.

$\ddagger$ This is a divergence from the generic distinction. 
Peristomium bearing the first foot with long dorsal and ventral cirri, and the ventral cirrus of the next segment long.

Pharynx exsertile, muscular, cylindrical, with papillæ round the margin; horny jaws.

Parapodia, first foot bearing only a few minute chætæ, conforming to the dorsal type.

Elytra, twelve to thirty-five or more; segments carrying these devoid of cirri.

Segmental organs opening ventrally on papillæ near the bases of the feet. Dorsal chætæ with more or less tapered simple tips, ventral chætæ with simple or bifid hooked tips.

Development by trochophores.

Twelve elytra.

SYNOPSIS OF GENERA.

\section{LePidonotus, Leach.}

Prostomium produced into the bases of the tentacles.

Fifteen elytra, covering the body entirely.

Prostomium produced into the bases of the tentacles.

Malmgrenia, McIntosh.

Tentacles, palps, and cirri smooth.

Eyes large, lateral, nearly forming a square.

Lateral tentacles arise underneath the base of the median.

\section{Gattyana, McIntosh.}

Tentacles and cirri densely covered with long cilia.

Elytra smooth to the naked eye, posterior and external margin with long cilia, segmental papillæ long.

HaRmothoE, Kinberg, char. em.

Posterior, pair of eyes, dorsal, anterior ventral, or on the extreme margin. Not always visible from the dorsum.

Segmental papillæ long.

Dorsal chætæ, well-marked spinous rows, smooth tips.

Ventral chætæ, simple-hooked tips, superiorly and inferiorly, median bifid.

\section{Antinö̈, Kinberg.}

Eyes as in Harmothoë.

Elytra, surface spinous, margin with short cilia.

Dorsal chætæ, long and tapering, well-marked spinous rows.

Ventral chætæ, long and slender, with elongated spinous regions and hair-like tips. 
Eunoa, Malmgren.

Eyes postero-lateral or lateral.

Elytra, surface tuberculate, margin ciliate.

Dorsal chætæ, minutely spinulous, tip pointed and bare.

Ventral chætæ somewhat longer, tip smooth, hooked, spinous rows large.

\section{Evarne, Malmgren.}

Eyes large, close together, postero-lateral in position.

Dorsal chætæ shorter than ventral, spinous rows large.

Ventral chætæ very long, with minutely bifid tips.

\section{Phyllantinoë.}

Cephalic appendages and elytra unknown.

Prostomium short and broad, median tentacle arising far backwards between the lobes. Eyes postero-lateral.

Fifteen elytra, not completely covering the body. About 40 segments.

LaGisca, Malmgren.

Body narrow and attenuate posteriorly.

Last 9-12 segments not covered by elytra.

Scalisetosus, McIntosh.

Elytra cover dorsum in front, but leave it uncovered posteriorly. Translucent.

Fifteen elytra, on anterior part of body only. About 100 segments.

Polynö̈, Savigny.

Palps, with dense rows of clavate papillæ.

Elytra, with broad belt of papillæ on anterior surface.

EnIPo, Malmgren.

Palps and tentacles smooth.

Elytra smooth, subcircular.

Eighteen elytra.

ACANThicolepis, Norman MS.

Elytra coarsely spinous, covering dorsum entirely.

Prostomium cleft to form two pointed lobes.

Tentacles and cirri ciliate.

\section{HALOSYDNA.}

Elytra large, soft, with frilled outer border.

Prostomium continuous, with tentacles; these and palps smooth.

Nuchal collar with prominent flaps. 
Numerous elytra. On segments $1,3,4,6, \ldots 25,28$ et seq. to end of body.

Acholö̈, Claparède.

Elytra entirely covering the body.

A T-shaped branchial process on the cirriferous parapodia.

Lepidasthenia, Malmgren.

Elytra not covering the body, except in very young specimens. Notopodium rudimentary.

\section{Genus LEPIDONOTUS, Leach.}

Body short, more or less linear. Anterior part of prostomium produced into the bases of the median and lateral tentacles. Palpi smooth or with papillæ in five longitudinal rows. Elytra, twelve pairs, covering the dorsum entirely and occurring on segments $1,3,4,6,8$ et seq. alternately.

*L. SQUamatus, Linn. Size about 1 inch or more.

Elytra entirely covering the body, conspicuously ciliate on outer and posterior margin.

*L. Clava, Mont. Size 2 inches or more.

Elytra not covering the body, except in young specimens; to the unassisted eye not ciliate.

Genus MALMGRENIA, McIntosh.

Head somewhat pyriform, with the narrow end in front, $*$ the median and lateral tentacles springing from the front, as in Lepidonotus. Eyes large, nearly forming a square.

Palpi, tentacles, and cirri smooth.

Segmental eminences fairly developed, but without papillæ.

Elytra, fifteen pairs, smooth, with the exception of a small group of papillæ at the anterior curve.

Dorsal chætæ translucent, short, and with faint spinous rows.

Ventral chætæ translucent, with rather short distal regions, and five rows of spines. The tip hooked, and a secondary process beneath.

* M. Castanea, McIntosh. Size $\frac{3}{4}$ inch.

Elytra smooth. Reniform examples, with a small and somewhat triangular group of papillæ near anterior curve.

Variously bordered with madder-brown.

M. ANDreapolis, McIntosh. Size 1 inch or more.

Elytra smooth. Reniform examples, with a belt of microscopic papillæ along anterior border. A brown ring, more or less complete, on the anterior, and after the sixth and seventh becoming a V-shaped mark with a spot.

‡ McIntosh's figures do not indicate this. 


\section{Genus GATTYANA, McIntosh.}

Lateral tentacles arising below the base of the median, they and the cirri densely covered with long cilia. Palpi, with numerous short clavate papillæ truncate at the tip.

Elytra, fifteen pairs, minutely spinous, covering all the dorsum and attached to seg nents $1,3,4,6,22-5$ et seq.

This genus has only recently been instituted by McIntosh on the ground of priority, the better-known name of Nychia being already appropriated.

*Gattyana cirrosa, Pallas. Size nearly 2 inches.

\section{GenUs HARMOTHÖ̈.}

Body not much elongated.

Lateral tentacles fixed below the median.

Palpi, with rows of minute truncate papillæ.

Eyes four, two on the lobes in front, the two posterior on the dorsum in front of the collar.

Elytra, fifteen pair, covering the whole of the dorsum.

Segmental papillæ long. Papillæ of proboscis $\frac{9}{9}$.

1. Lateral tentacles distinctly shorter than the prostomium.

(a) Posterior eyes not in contact with nuchal border.

Four eyes, visible from the dorsum.

*H. Marphyser, McIntosh. Size about $\frac{3}{4}$ inch.

Prostomium deeply cleft, lobes somewhat rounded. Eyes small.

Elytra rather thin, smooth, and pellucid. A belt of small papillæ (spines) in front of scar.

$\dagger$ H. maxillospinosa, St. Joseph. Size nearly $\frac{3}{4}$ inch.

Prostomium, with small, narrow cleft.

Median tentacle on a very broad base.

Jaws bristling with chitinous spines.

Two eyes, visible from the dorsum.

H. ANTILOPIs, McIntosh. Size nearly 1 inch.

Prostomium somewhat deeply cleft, lobes subconical.

Elytra having long cilia on the outer border.

$\uparrow$ H. PICTA, St. Joseph. Size 1 inch.

Prostomial cleft widely V-shaped.

Three tentacles, papillose, subulate, on stout dark brown bases.

(b) Posterior eyes in contact with nuchal border.

H. zetlandica, McIntosh. Size about $\frac{1}{2}$ inch.

Prostomial cleft broad, not very deep.

Elytra, with a few minute papillæ, though apparently smooth. 
$\dagger$ H. LJungmani, Malmgren. Size $\frac{1}{2}$ inch or little more.

Prostomial cleft deep, not very broad.

Elytra fairly uniformly papillose, a very few minute cilia on margin.

2. Lateral tentacles about the length of the prostomium.

Four eyes, visible from the dorsum.

*H. Lunulata, Delle Chiaje. Size about $\frac{3}{4}$ inch.

Prostomium deeply cleft, lobes somewhat rounded.

Elytra finely veined, margin smooth, a cluster of fine spines in front of scar.

*H. SPINIFERA, Size nearly 1 inch.

Prostomium elongate, deeply cleft, lobes subconical.

Elytra, the first light-coloured, the second nearly black, the remainder becoming lighter. Spinose near the outer border, where a few clavate cilia exist.

*H. setosissima, Savigny. Size to $1 \frac{3}{4}$ inches.

Prostomium broad, somewhat deeply cleft, lobes rounded.

Elytra densely covered with minute papillæ, a few clavate cilia on outer border.

*H. areolata, Grube. Size $\frac{3}{4}$ inch.

Prostomial cleft somewhat deep, wide, a slightly curved V-shape. Elytra leathery, marked in irregular polygonal areas.

Posterior and outer margin with long cilia.

†H. CALLIACA, St. Joseph. Nearly $\frac{3}{4}$ inch.

Prostomium broad. Tentacles and cirri with long tapering papillæ. Eyes postero-lateral.

†H. ARenicole, St. Joseph. Size 1 inch.

Prostomium nearly quadrangular, the anterior border with small semicircular depression in the centre.

Three tentacles finely papillose, subulate.

3. Lateral tentacles distinctly longer than the prostomium.

H. Frazer-Thomsoni, McIntosh.

Four eyes, visible from the dorsum.

Elytra, margin smooth.

*H. imbricata, Linn. Size to 2 inches.

Posterior eyes, only visible from the dorsum.

Elytra, margin with small clavate cilia. 
†H. Reticulata, Claparede. Size nearly 1 inch.

Elytra marked with black spots, margin richly ciliate.

Median tentacle $2 \frac{1}{2}$ times the length of the lateral.

H. HaliaËTi, McIntosh.

No perfect specimen known.

$\dagger$ †. TORquata, Claparède. Size $\frac{1}{2}$ inch.

Sixteen elytra. Margin smooth, except the first four.

$\dagger$ H. SARniensis, Lankester. Size to 2 inches.

Twenty elytra. Lateral tentacles as long as prostomium, median tentacle three times as long.

Genus EUNOA, Malmgren.

Lateral tentacles arising under the median, below and slightly internal to the peaks of the head. Palpi, with six rows of short cilia. Eyes large, visible from the dorsum.

Elytra, fifteen pairs, occurring on segments $1,3,4,6, \ldots 22,25$, etc. External aperture of the segmental organs indicated by blackish pigment. No papillæ.

*E. Nodosa, Malmgren. Size $2 \frac{1}{4}$ inches.

Prostomium cleft to half its length.

Eyes four, large, lateral, the anterior about the level of a median transverse line.

E. tritoni, McIntosh. Size nearly $1 \frac{1}{2}$ inches.

Prostomium cleft to form two minute lobes.

Eyes four, moderate size, equal, the four median as regards length.

Genus EVARNe, Malmgren.

Body rather small, ovate oblong, attenuate posteriorly.

Lateral tentacles fixed under the median, prostomium deeply incised in front, and with prominent lateral peaks.

Eyes four, generally large, the anterior pair on the projecting lateral region, the posterior in front of the nuchal collar and widely separated.

Palpi densely covered with minute papillæ.

Elytra, fifteen pair, spinulose, ciliated or smooth at the edge.

Dorsal bristles shorter than the ventral, and with wide rows of spines; ventral bristles very long, with minutely bifid tips.

Segmental papillæ well marked, but not long.

*E. IMPar, Johnston. Size 1 inch.

Elytra, with densely ciliated margin. More posterior portion papillose, often increasing to spines, and on the border large pyriform or globular papillæ.

¥ Segmental papillæ are described by McIntosh for both the species assigned to this genus. 
E. Johnstoni, McIntosh. Size nearly $\frac{1}{2}$ inch.

Elytra, margin with few long and somewhat fusiform cilia.

Surface, with rather large conical horny papillæ, often with blunt spinous tips.

E. Hubrechti, McIntosh. Size $\frac{1}{2}$ inch and over.

Elytra thin but tough, margin smooth, surface minutely granular under a lens.

E. Atlantica, McIntosh.

Elytra unknown.

Specimen imperfect, resembling E. impar.

E. Pentact e, Giard.

Elytra resembling $E$. impar. Median tentacle only half as long again as lateral. Two dark bands on tentacular cirri.

\section{Genus LAGISCA.}

Body rather narrow, attenuate posteriorly.

Prostomium cleft. Lateral tentacles attached below the median.

Eyes four, lateral, two just in front of a median transverse line, two in front of the nuchal border.

Elytra fifteen, covering the dorsum except the last few.

Notopodial chætæ, with acute tips and finely serrated.

Neuropodial chætæ, simple superiorly and inferiorly, rest bidentate, the rest with long spinous rows.

Papillæ of proboscis $\frac{9}{9} . \ddagger$

Nephridial papillæ beginning as a minute process on the fifth foot and extending nearly to the last. Much smaller than in Harmothoë.

* L. Floccosa, Savigny. Size about $1 \frac{1}{2}$ inches.

Prostomium deeply cleft.

Elytra, most of the surface minutely and densely spinulose, and soft globular papillæ near posterior margin. Outer margin with a few short slender cilia.

L. Elizabetha, McIntosh. Size $\frac{1}{2}$ inch, or rather more.

Prostomium, with shallow crescentic depression separating lobes.

Elytra resembling those of $L$. floccosa, but with external margin richly provided with long clavate cilia, which become reduced posteriorly.

L. Jeffreysir, McIntosh. Size nearly $\frac{3}{4}$ inch.

Prostomium somewhat deeply but narrowly cleft.

Elytra, most of the surface minutely and densely spinulose. External margin with long filiform cilia.

$\ddagger$ Mc Intosh figures $\frac{8}{8}$ papillæ for the proboseis of $L$. floccosa. 
*L. extenuata, Grube. Size $1 \frac{1}{4}$ inches.

Prostomium somewhat deeply cleft.

Elytra, most of the surface minutely and densely spinulose. External margin richly provided with long pellucid cilia.

*L. Rarispina, Malmgren. Size $1 \frac{1}{2}$ inches.

Closely resembling $L$. floccosa. Spines on elytra larger.

Two curved chætæ arise dorsally from the base of the tentacular cirri.

Genus SCALISETOSUS, McIntosh.

Anterior border of the head smoothly rounded.

Eyes placed close together on each side, while the right and left pairs are widely separated and placed far back.

Palpi smooth. Proboscis somewhat thin.

Body of moderate length. Scales cover the dorsum in front, but leave the centre bare posteriorly.

Segmental eminence distinct, but papillæ small.

Chætæ transparent as crystal; dorsal slightly curved, and with from five to eight very distinct rows of spines. Ventral bristles slender, elongate, with close spinous rows, and hooked and bifid tip.

†S. Communis, Delle Chiaje. Size $\frac{3}{4}$ inch.

Median and lateral tentacles long, with numerous short clavate cilia.

*S. Assimilis, McIntosh. Size $\frac{3}{4}$ inch.

Median tentacle long, lateral short; all smooth.

A blackish brown median band down the back.

†S. ECHINI, Giard. Size $1 \frac{1}{4}$ inch.

Resembling S. assimilis. An irregular band of green down the back.

Genus POLYNÖ̈, Savigny.

Head elongated antero-posteriorly, with a somewhat indistinct peak on each side, beneath which is the lateral tentacle.

Anterior and posterior eyes widely separated.

Palpi, with dense rows of clavate papillæ.

Body linear elongate, with many segments.

Segmental papillæ long.

Elytra, fifteen pairs, with a broad belt of papillæ on the surface anteriorly.

Notopodium minute, with small spinous chætæ truncated at the tip.

Neuropodium has a single, strong, hastate chæta superiorly, and below, strong bifid chætæ with short spinous regions.

* Polynö̈ scolopendrina, Savigny. Size to 5 inches.

NEW SERIES, -VOL, VI, NO, 2 . 


\section{Genus HALOSYDNA, Kinberg.}

Body linear oblong; head continuous anteriorly with the bases of the median and lateral tentacles.

Eyes large. Palpi smooth. Nuchal collar with a prominent flap.

Segmental eminences distinct and the papillæ long.

Proboscis, with twenty-two frilled papillæ along each border.

Elytra, eighteen pairs, large, soft, and with a frilled outer border, not covering the dorsum.

Notopodium minute, with slender, simple, and finely spinous chætæ.

Neuropodium rather long, with numerous somewhat slender chætæ with tips of varying breadths.

*Halosydna gelatinosa, M. Sars. Size to $3 \frac{1}{2}$ inches.

\section{Genus ACHOLÖ̈, Delle Chiaje.}

Head elongated from before backward and running into the bases of the tentacles.

No peaks. Four large, equidistant eyes. Palpi smooth and short. Body sublinear, flattened; segments numerous.

A segmental eminence, but no distinct papilla.

Cirri on every foot, and a T-shaped branchial process.

Elytra numerous.

Parapodia short, notopodium minute, chætæ few and small, with a minute hook at the tip. Neuropodium bearing chætæ with long and strong shafts and short spinous regions having a sharp hook at the tip.

*Acholoë astericola, Delle Chiaje. Size to 2 inches or more.

\section{Genus LEPIDASTHENIA, Malmgren.}

Corpus elongatum, sublineare depressum.

Oculi 4, utrinque bini approximati, laterales, par anterius in vel pone medium lobi cephalici.

Antennæ una cum tentaculo e parte anteriore lobi cephalici productæ.

Elytra minuta posteriora versus magnitudine decrescentia, maximam partem dorsi nudam relinquentia, in segmentis pedibus instructis $1,3,4,6,8, \ldots 20,22,25,28, \ldots 79-82$ obvia.

Ramus superior pedis perminutus acicula sola præditus, setis omnino carens. Setæ rami inferioris infra apicem subrectum bidentatum, dentibus subrectis, paullo dilatatæ serrulatæ; 1 1. 2 superiorum ceteris plerumque duplo validiores et crassiores apice integro, margine altero vero dentibus paucis serrato.

Cirri anales 2 breves poneanum dorsualem. [Malmgren.]

*Lepidasthenia argus, sp. nov. Size to 8 inches (see p. 250). 


\section{FAMILY SIGALIONID无.}

Prostomium rounded, often with a nuchal collar posteriorly.

No facial tubercle. Median tentacle, when present, generally long, produced from the median part of the prostomium and with ctenidia at the sides of the base (ceratophore).

Lateral tentacles fused with the base of the tentacular cirri, the tips only emerging.

Eyes four, occasionally only two, or absent.

Palpi long, attenuate, and smooth, with buccal ctenidia at the bases.

Body long and narrow.

Pharynx, with $\frac{9}{9}, \frac{11}{11}, \frac{13}{13}$ papillæ and teeth.

First pair of feet carried in front of the head.

Notopodial chætæ spinous and tapering.

Neuropodial chætæ compound, the terminal region being often long, multiarticulate, and bifid.

Ctenidia on all the feet.

Elytra and cirriform gills alternate in the anterior segments up to the twenty-sixth; those of the middle and posterior part furnished with both elytra and cirriform gills.

Sthenelais, Kinberg.

Elytra partly fringed with a variable number of minute papillæ, entirely covering the dorsum.

Eusthenelais, McIntosh.

Elytra unknown. Known only from a fragment.

Sigalion, $A u d$. et $E d w$.

Elytra partly fringed with pinnate processes, or with long papillæ arising from an axis; entirely covering the dorsum.

Leanira, Kinberg.

Elytra not covering the dorsum anteriorly, smooth in outline and surface.

A median and two lateral tentacles.

Pноцоё, Johnston.

Elytra partly fringed with long cilia with moniliform tips. Median portion of dorsum exposed.

A median tentacle only. Two pair of eyes.

\section{Genus STHENELAIS.}

Prostomium rounded anteriorly, with a nuchal collar posteriorly in the preparations.

A pair of ctenidia at the base (ceratophore) of the median tentacles.

Lateral tentacles fused with the first foot; tentacular cirri more or less separate. 
Palpi long, subulate and smooth, springing from the ventral surface of the prostomium, but fusing with the first foot.

A pair of scoop-shaped ctenidia at the base.

Elytra covering the dorsum, fringed.

Noto and neuropodia of equal lengths.

Segmental eminence at the base of each foot, and a ciliated funnel-shaped process on the foot.

A well-developed branchial process on every foot, and on the dorsal ridge beneath it three $\mathrm{T}$-shaped ciliated organs.

Notopodial chætæ long, stiff, finely tapered, and spinous.

Neuropodial chætæ, upper ones with simple tips, boldly spinous; next come compound bristles at first, with a terminal region of three segments, then with one joint, and at the ventral edge with one to four joints, all with bidentate tips. They are arranged in the foot after the outline of a horseshoe, in transverse section.

*S. BOA, Johnston. Size to 8 inches.

Prostomium, with broad, crescentic depression on the anterior border. Eyes four, antero-lateral in position; the anterior, the largest, are almost hidden by the ctenidia.

S. zetlandica, McIntosh. Size 2 inches and more (?).

Specimen fragmentary. Head unknown.

†S. atlantica, McIntosh. Size unknown.

Prostomium divided into two lobes by a slight median depression. Median tentacle subulate and with a terminal joint. Eyes four, one behind the other in the middle of the anterior border of each lobe.

*S. LIMICola, Ehlers. Size 2 inches and more.

Prostomium ovoid laterally, base of median tentacle large and cylindrical (conical in spirit), eyes four, posterior just behind base of median tentacle, the anterior usually concealed by the ctenidia.

S. Jefrreysir, McIntosh. Size 2 inches (?).

Prostomium broadly ovate, bearing a long median tentacle on a short base. No eyes visible (in a preparation).

†S. MINor, Pruvot and Racovitza. Size 2 inches (?).

Prostomium resembling that of $S$. limicola, but with small processes on the inner border of the ventral tentacular cirrus. In S. limicola they are large. 
Genus SIGALION, Audouin and Milne Edwards.

Prostominm elongate from before backwards.

Median tentacle absent, lateral tentacles short and papilliform, fixed to the anterior part of the prostomium.

Elytra covering the dorsum; marginal processes pinnate, or with long papillæ from the axis.

The parapodia resemble those of Sthenelais, notopodium clavate and furnished with a papilla. Chætæ as in Sthenelais. Neuropodium somewhat truncate and with a papilla internal to the chætæ, which are all bifid.

Branchiæ on every foot (S. Matild $\alpha$ ).

Segmental eminence placed ventrally at the base of each foot.

$\uparrow$ S. Matilde, Aud. \& $E d w$. Size to 5 inches.

Four eyes, near the centre of the prostomium.

S. BuskI, McIntosh. Eyes unknown.

\section{Genus PSAMMOLYCE, Kinberg.}

Caput antenna singula et 2 aut 4 oculis; proboscis armata; primi pedes antice ultra caput porrecti, cirrus tentacularibus instructi ; pedes ceteri quasi uniremes; elytra medium dorsi haud tegentia, margine fimbriato, papillis obsita. [Carus.]

Psammolyce Herminia, Aud. \& Ed.

\section{GENus PHOLOË, Johnston.}

Prostomium furnished with a short median tentacle.

Eyes, two pairs, more or less connate.

Body linear oblong; elytra on alternate segments in the anterior part of the body; posteriorly a pair on each segment.

First foot with two tentacular cirri, without chætæ.

Notopodium with slender, tapering, spinous chætæ.

Neuropodium with stout, falcate, compound chætæ.

P. Minuta, O. Fabricius.

Tentacle and cirri somewhat papillose. Size $\frac{3}{4}$ inch.

†P. synophthalmica, Claparede.

Tentacle and cirri swollen at the base; two of the cirri papillose. 
LIST OF BRITISH SPECIES, INCLUDING THOSE RECORDED FROM THE ENGLISH CHANNEL.

* Found on the coast of Devon and Cornwall.

$\uparrow$ Found in the Channel, but not on the British Coasts.

\section{AMPHINOMID压.}

AMPHINOMINA.

Paramphinome, Sars.

P. pulchella.

Eurytнов̈, Kinberg.

$\dagger \mathrm{E}$. borealis.

\section{EUPHROSYNINA.}

SPINTHER, Johnston.

S. oniscoides.

S. miniaceus.

Euphrosyne, Savigny.

*E. foliosa.

E. armadillo.

E. Robertsoni.

$\dagger \mathrm{E}$. intermedia.

\section{APHRODITID压.}

ApHrodita, Linnceus.

*A. aculeata.

Lemtmatonice, Kinberg.

$\dagger$ L. filicornis.

L. producta.

Hermione, Blainville.

${ }^{*} \mathrm{H}$. hystrix.

\section{POLYNOID正.}

Lepidonotus, Leach.

* L. squamatus.

* L. clava.

$\dagger \mathrm{L}$. pleiolepis.

Gattyana, McIntosh.

${ }^{*} \mathrm{G}$. cirrosa.

Eunoa, Malmgren.

*E. nodosa.

E. tritoni.

\section{POLYNOID君.}

LaGisOA, Malmgren.

${ }^{*}$ L. floccosa.

L. Elizabethæ.

L. Jeffreysii.

*L. extenuata.

*L. rarispina.

Acanthicolepis, Norman MS.

A. asperrima.

НАвмотнов̈, Kinberg.

*H. imbricata.

*H. spinifera.

$\mathrm{H}$. zetlandica.

$\dagger$ H. Ljungmani.

H. antilopis.

H. Haliaëti.

H. Frazer-Thomsoni.

${ }^{*} \mathrm{H}$. marphysæ.

*H. lunulata.

*H. setosissima.

${ }^{*} \mathrm{H}$. areolata.

$\dagger$ H. cæliaca.

$\dagger \mathrm{H}$. maxillospinosa.

$\dagger$ H. picta.

$\dagger \mathrm{H}$. arenicolæ.

$\dagger \mathrm{H}$. reticulata.

$\dagger \mathrm{H}$. torquata.

$\dagger$ H. Sarniensis.

Evarne, Malmgren.

*E. impar.

E. Johnstoni.

E. Hubrechti.

E. atlantica.

$\dagger$ E. pentactæ. 
LIST OF BRITISH SPECIES, ETc.-continued.

\section{POLYNOIDE.}

AnTINoË, Kinberg.
A. Sarsi.
A. finmarchica.
A. mollis.

Phyllantinoë, McIntosh. P. mollis.

Scalisetosus, McIntosh.

$+\mathrm{S}$. communis.

${ }^{*} \mathrm{~S}$. assimilis.

† S. echini.

Malmgrenia, McIntosh.

* M. castanea.

M. andreapolis.

Halosydna, Kinberg.

*H. gelatinosa.

Polynö̈, Savigny.

*P. scolopendrina.

EnIPo, Malmgren.

E. Kinbergi.

Aсноцов̈. Claparède.

*A. astericola.

Lepidasthenia.

${ }^{*}$ L. argus.

\section{ACOETID压.}

Panthalis, Kinberg.

P. œrstedi.

\section{SIGALIONID正.}

Sthenelais, Kinberg.

${ }^{*} \mathrm{~S}$. boa.

S. zetlandica.

$\dagger$ S. atlantica.

${ }^{*} \mathrm{~S}$. limicola.

S. Jeffreysii.

$\dagger$ S. minor.

S. sp.

Eusthenelais, McIntosh.

E. hibernica.

Sigalion, Audouin $\& M$. Ed.

$\dagger$ S. Mathildæ.

S. Buskii.

Psammolyce, Kinberg.

$\dagger \mathrm{P}$. Herminiæ.

Leanira, Kinberg.

L. hystricis.

Pноцов̈, Johnston.

P. minuta.

$\dagger$ P. synophthalmica.

The following species are recorded on the French coast, but I have not sufficient information to assign to them their right position :-

Polynoë lævis, Audouin and M. Edwards.

Lænilla alba, Malmgren.

Hermadion variegatum, $G r$. et $K r$. 


\title{
DISTRIBUTION OF SPECIES.
}

\author{
†EURYThoe borealis, Sars.
}

This species has been recorded by McIntosh from under a stone in a tide pool at Herm. This author regards it as rare in British waters, but Benham (3) remarks that specimens six inches long occur all round the British area. Taking the size of the animal into consideration, it is doubtful if the two authors refer to the same species.

LOCALITY.

Herm . . Tide pool . . McIntosh (16).

\section{*Euphrosyne foliosa, Audouin and Edwards.}

A species which is by no means uncommon. Its colour is some shade of orange-red, but this has something of a greyish character in many specimens. Those taken from Plymouth Sound are often partially concealed by a covering of flocculent detrital matter. The animal occurs in the holes of rocks and stones brought up by the dredge; it has also been found on the fine gravel of Ground XIV (1) in the neighbourhood of the Eddystone.

Of the numerous species of Polychætes described by McIntosh in his recent Monograph (20) a large number are noted as being deep-water forms in the north, but as their range of distribution passes to the south, so they make their home in shallower or even tidal waters. This species is a case in point, but I have never met with it in tidal waters.

Pruvot + (29) records it from the Fucus zone, the Himanthalia zone to the gravel of the base of his littoral zone.

\section{LOCALITIES.}

Plymouth : Millbay Channel, Duke Rock, Mewstone Grounds, Stoke Point.

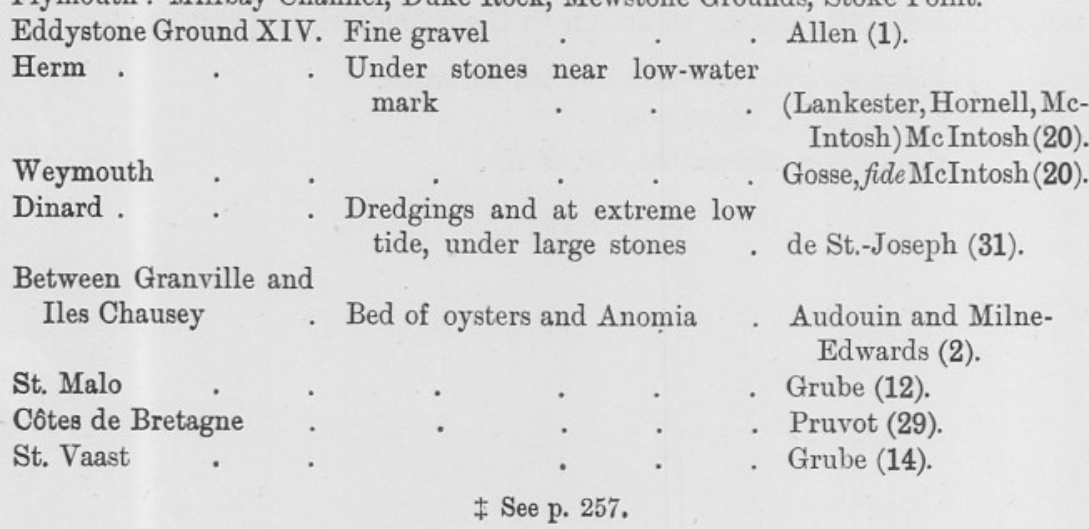




\title{
†Euphrosyne intermedia, St.-Joseph.
}

Recorded once only from a dredging near la Conchée, Dinard, by de St.-Joseph.

$\mathrm{McIntosh}$ is inclined to regard this as only a variety of $E$. foliosa.

\author{
LOCALITY. \\ Dinard (la Conchée) . Dredging . . . de St.-Joseph (31). \\ * Aphrodita aculeata, Linn.
}

This, the common sea-mouse, is a well-known and widely distributed species. Though so common, it is not often taken by the Association in their dredging and trawling operations, but considerable numbers are brought into the port by the local fishermen, and some of these are of very large size.

Möbius (27), dealing with the North Sea, states that it frequents a soft bottom of mud, muddy sand, or sand and shells, shells, sand, and small stones, to a depth of 100 fathoms and over.

Pruvot (29) records it from the Himanthalia zone among seaweeds, where the bottom is sandy, on the coast of Brittany, and from coastal mud or sand of the open sea in the Golfe du Lion.

\section{LoCALITIES.}

Plymouth: Penlee, 3-6 miles S.W. (R. A. T.), Rame Head, 2-5 miles S.W. (R. A. T.), Stoke Point, Mewstone Grounds.

Eddystone Grounds III.,

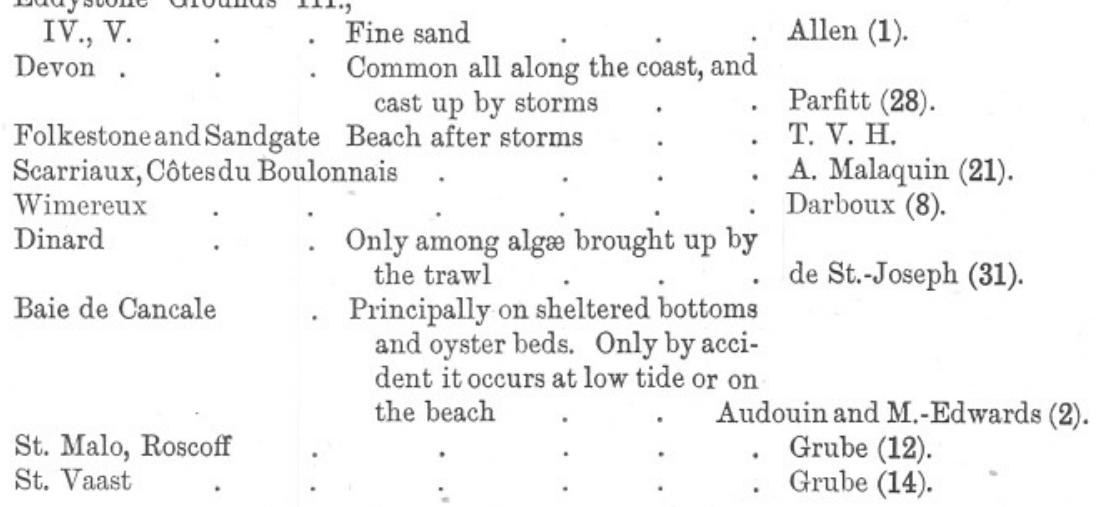

\section{$\dagger$ Latmatonice filicornis, Kinberg.}

As regards the Channel this species has only been taken on the oyster ground off St. Peter Port, Guernsey, along with Hermione (McIntosh, 20). It appears to be a northern species, and is found at considerable depths, chiefly on muddy sand.

Möbius (27) records it on mud in the North Sea.

St. Peter Port, Guernsey

Locality.

- McIntosh (16). 


\section{* Hermione hystrix, Savigny.}

Rather common. It occurs chiefly on the gravel grounds in the neighbourhood of the Eddystone at a depth of about 30 fathoms.

McIntosh (20) records it as partial to shell débris, gravel, and similar regions, while Pruvot (29) finds it on the coast of Brittany in the littoral zone. In the middle (Himanthalia) region of this zone it occurs among seaweed on a sandy bottom, and lower down it lives on a coarse sand, passing to fine sand at greater depths.

\section{LOCALITIES.}

Plymouth: Stoke Point; Mewstone Ledge ; Rame Head, 3 miles S.W.; 3-6 miles S.W. (R. A. T.) ; Penlee, 5 miles S.W. (R. A. T.).

Eddystone IX., X. . Coarse gravel with sand or mud. Allen (1).

St. Peter Port, Guernsey Shell-gravel, ete. . . McIntosh (20).

Côtes du Boulonnais . Dredgings . . . A. Malaquin (21).

Dinard . Common enough on the shore and at extreme low tide, and in dredgings at all depths . de St.-Joseph (31).

Baie de Cancale . . On oyster beds . . . Audouin and Milne-

Iles Chausey . . Among seaweeds on a muddy bottom, exposed only at the very lowest tides , . Audouin and MilneEdwards (2).

Edwards (2).

Côtes de Bretagne . $\quad$. $\quad$. . . . Pruvot (29).

\section{* Lepidonotus squamatus, Linn.}

This is one of the most abundant species, and occurs everywhere and in all situations from between tidemarks to deep water.

It is not infrequent on the shore under stones, and occurs in the holes and crevices of stones brought up by the dredge, as well as in the miscellaneous collection of material which includes Choetopterus tubes and a varied assortment of Hydroids and Polyzoa from all parts visited by the Association.

Möbius, writing with reference to the North Sea, gives as its habitat stones, sand, and shells; sandy mud; sand with small stones and shells; dead zostera (27); red algæ; stones, sand, and red algæ (Baltic) (26).

Pruvot (29) confines it to tidal waters at all levels, and the laminarian zone on stony ground of various kinds.

Plymouth: Area general.

\section{Localities.}

Eddystone Grounds . Fine sand; coarse gravel with sand or mud; fine gravel; shell-gravel ; stones . . Allen (1).

Salcombe . . Coralline region . . Parfitt (28).

Falmouth, South Devon, Weymouth . . . Johnston (16). 


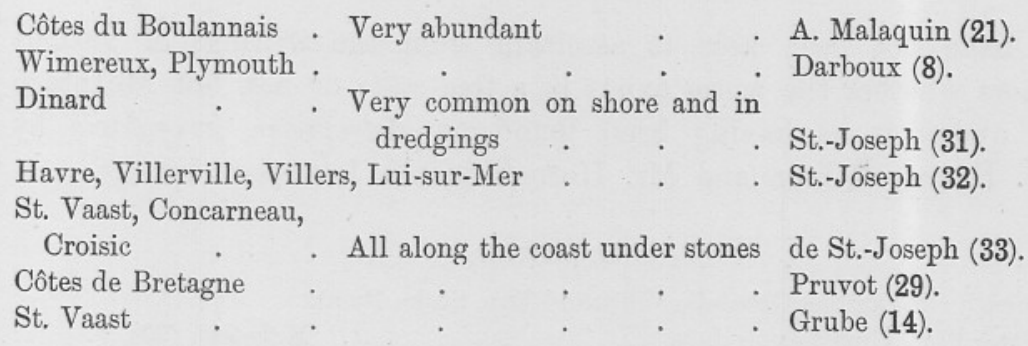

* Lepidonotus clata, Montagu.

This species is very common, but by no means so abundant as the last, and is more restricted in its distribution. It occurs below tidemarks, but between them it is most numerous at extreme low water under stones. All authors seem to agree in limiting the size of this species to something like an inch and a half, but local specimens of such a size would be regarded as small. They frequently occur up to $2 \frac{1}{4}$ inches, and sometimes even more. Under these circumstances the elytra are widely separated, and a very good figure of the worm in this condition is given by Bourne (4). Pruvot (29) records it from the higher strata of tidal waters among fucus-covered rocks in the Channel, and from the same zone in the Golfe du Lion in the Mediterranean.

\section{LOCALities.}

Plymouth: Breakwater, Cattewater, Rum Bay, Wembury Bay, the Bridge.

South Devon, Falmouth . . . . Johnston (16).

Wimereux . . . . . . Darboux (8).

Concarneau, St. Jean de Luz, Croisic . . . . . St.-Joseph (32).

Côtes de Bretagne . $\quad$. $\quad$. . Pruvot (29).

† Lepidonotus pleiolepis, v. Marenzeller.

The species described under this name is recorded from the Japanese seas, and is characterised by the possession of 15 elytra, a fact which should lead to a modification of the genus. St.-Joseph describes a specimen from Cézembre, which he assigns to this species. As it only possesses 12 elytra and is very small, he somewhat apologetically explains that it is only a young one.

\section{LOCALITY.}

Dinard (Cézembre) . Dredging $20 \mathrm{~m}$. . . . de St.-Joseph (31).

\section{* Malmgrenia castanea, McIntosh.}

By no means uncommon. This species has, in this locality at least, only been found as a commensal on the under surface near the mouth of Spatangus purpureus, and is therefore found on the same kind of ground as that frequented by the echinoderm. 
I have not been able to ascertain from the writings of various authors whether the worm exists in a free state or not, but McIntosh (20) quotes it as having been found on Astropecten irregularis by Prof. Harvey Gibson and Mr. Hornell in the Liverpool district.

\section{Localities.}

Plymouth: Mewstone Grounds, Whitsand Bay, Stoke Point.

St. Peter Port, Guernsey . . . . McIntosh (20).

St. Vaast . . Dredgings . . . de St.-Joseph (32).

*Gattyana cirrosa, Pallas.

This species is perhaps better known under its older name of Nychia, which has been relegated to obscurity by McIntosh.

It is a fairly common species in the vicinity of Plymouth. It is found in the dredge material from the Eddystone grounds in a manner which, if it does not occur free, does not indicate a very close relation between it and its host. At Salcombe it has recently been taken in some numbers in the tubes of Amphitrite Johnstoni. It is essentially a commensal, and has been found in the tubes of Chcetopterus variopedatus (Baird, fide McIntosh, 20; Hornell, 15); Thelepus cincinnatus (Hornell, 15); Amphitrite figulus (Dalyell, 20). Malaquin describes a definite variety from the tubes of Chcetopterus on the Côtes du Boulonnais. Pruvot records it only from the zostera region, where the bottom is sandy.

\section{Localities.}

Plymouth: Mewstone, Eddystone, Yealm (with Amphitrite Johnstoni, R. A. T.).

Salcombe . Commensal with Amphitrite

South Devon . . . . . . Johnston (16).

Herm, Channel Islands . . . . McIntosh (20).

Côtes du Boulonnais . Chcetopterus tubes . . Malaquin (21).

Dinard . . Chotopterus tube . . de St.-Joseph (31).

St. Malo . . . . . . Grube (12).

Côtes de Bretagne $\quad . \quad$. $\quad . \quad$. . Pruvot (29).

St. Vaast $\quad . \quad$. . . . . . Grube (14).

\section{*Harmothoü marphysa, McIntosh.}

This species is not yet known from the Plymouth district, though its host, Marphysa sanguinea, is fairly common. McIntosh records it from the Cornish coast.

\section{LOCALities.}

$\begin{array}{llll}\text { Polperro } & \text {. Chinks in rocks . } & \text { McIntosh (20). } \\ \text { Guernsey } & \text {. Galleries of } M \text {. sanguinea } & \text {. Mc Intosh (20). } \\ \text { Roche Bernard . } & \text {. Côtes du Boulonnais } & \text {. } & \text { Malaquin (21). }\end{array}$




\section{†HaRmothö̈ Maxillospinosa, de St.-Joseph.}

Recorded from Dinard by de St.-Joseph, who found it several times in dredgings. Pruvot's laminarian (gravel) region.

\section{$†$ †аRмотнӧ̈ PICTA, de St.-Joseph.}

First recorded from Dinard, where de St.-Joseph found a single specimen on the shore in an empty tube of Lanice conchilega, and subsequently it was found in greater numbers, and from other localities on the French coast, where it occurred as a tidal form.

\section{Localities.}

Dinard . . . Tubes of Lanice . . . de St.-Joseph (31).

St.Jeande Luz,Hendaye Under stones . . de St.-Joseph (32).

\section{†HaRmothoё LuUngmani, Malmgren.}

Not yet recorded from the neighbourhood of Plymouth. McIntosh records it as a tidal and a deep-water form, but Pruvot only includes it in his laminarian zone.

\section{Localities.}

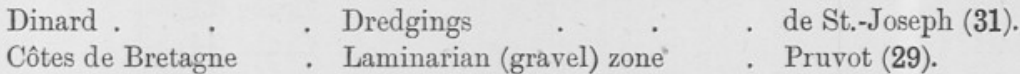

* Harmothö lunulata, Delle Chiaje.

A not uncommon tidal form. It may be found among the laminarian roots on the Plymouth Breakwater, and occasionally hidden under stones near low water.

Hornell (15) states that this species may be found in the ambulacral grooves of Astropecten irregularis.

\section{LOCALITIES.}

Plymouth: Breakwater, the Bridge, Rum Bay.

Salcombe.

Channel Islands

- MeIntosh (20).

\section{*Harmothoe spinifera, Ehlers.}

This is a very common species at Plymouth, and one in which the colouration, always presenting a wide range in the Polynoids, is sufficiently constant to make it readily recognisable. It is found in all parts of the Sound where rocks and stones occur, in the crevices of which it appears to dwell.

Pruvot (29) notes it from the laminarian region only, which corresponds with my experience, though McIntosh (20) gives a locality which is apparently within tidal limits. 


\section{LOCALITIES.}

Plymouth: Millbay Channel, Duke Rock, Queen's Ground.

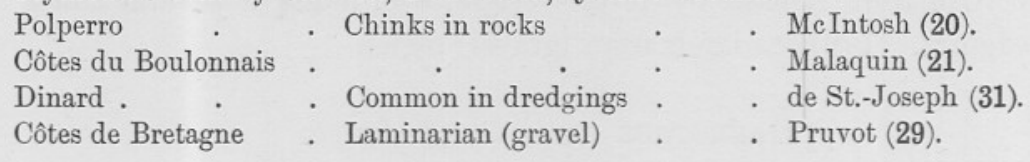

* HaRmothö̈ setosissima, Savigny.

McIntosh (20) records it both as a tidal and deep-water species, in the latter case also as an inhabitant of Chcetopterus tubes. It is occasionally found among the Polyzoa (Cellaria) and Chcetopterus tubes from the Eddystone Grounds. I have only seen a few examples.

\section{LOCALITIES.}

Plymouth: Eddystone Grounds.

Plymouth (E. M.) . . . . McIntosh (20).

Salcombe.

Herm, Channel Islands _ . . . McIntosh (20).

Herm . Chactopterus tubes . . Lankester (19).

Côtes du Boulonnais . Chatopterus tubes . . Malaquin (21).

St. Vaast . . Dredgings . . . . de St.-Joseph (32).

Roscoff . . . . . . . . Grube (21).

St. Vaast . . . . . . . Grube (14).

*Harmothö areolata, Grube.

Not uncommon on the Eddystone Grounds, where the dredge or trawl brings up masses of Polyzoa, Hydroids, and Choetopterus tubes.

Localities.

Plymouth: Eddystone Grounds.

Herm, Channel Islands Tubes of Chotopterus (Cooper), and under stones . . McIntosh (20).

Herm . . . Under stones and in or near tubes of Terebella nebulosa . E. Ray Lankester (17).

Côtes du Boulonnais . Dredgings, Choetopterus tubes, rarely on shore . . Malaquin (21).

Dinard . . . Rare in dredgings; young only . de St.-Joseph (31).

Côtes de Bretagne . Fucus zone . . . Pruvot (29).

†HARMothö̈ ·. CALIACA, de St.-Joseph.

Recorded only from Dinard by de St.-Joseph, who found it on several occasions in dredgings. Pruvot's laminarian (gravel) region.

†HARMOthö̈ ARENICOLA, de St.-Joseph.

Recorded only from Dinard by de St.-Joseph, who found it on the shore attached to a specimen of Arenicola. 


\section{* Harmothö̈ imbricata, Linn.}

Not an abundant species, but at the same time fairly common. McIntosh regards the Channel as very near its limit of distribution, its place being taken in the south by Lagisca floccosa. In the neighbourhood of Plymouth it occurs between tidemarks and in deeper water. It is found among broken shells or stones covered with sponges, hydroids, polyzoa, and Choetopterus tubes on the Eddystone Grounds, and also under laminarian roots and suchlike crevices on the Breakwater.

McIntosh (20) gives similar localities, and adds the tubes of Terebella and Chcetopterus, and also old shells with Polycirrus.

Pruvot (29) finds it on the coasts of Brittany, in the Fucus as well as the Cystoseira zones of tidal waters, but he does not notice it in the laminarian zone.

Möbius (26), referring to the Baltic, finds it among zostera and red algæ, also on sand, mud, and muddy sand of various qualities, to a depth of nearly 100 fathoms. Again in the North Sea (27) he adds 10 fathoms to the depth, and as habitat, stones, shells, etc., variously combined with sand, mud, or both.

\section{LOCALITIES.}

Plymouth: Breakwater, Rum Bay.

Eddystone Grounds III, and VII. fine sand ; XVI. shell gravel, [T.V.H.] Allen (1).

Torbay .

- Gosse (10).

South Devon . $\quad$. $\quad$. . . Johnston (16).

Channel Is., Guernsey . Rare . . . . MeIntosh (20).

Côtes du Boulonnais . Under stones and in dredgings . Malaquin (21).

Dinard .

. de St.-Joseph (31).

Granville, Noir-moutier, and coasts of Brittany . . Audouin and

Côtes de Bretagne . Littoral zone . . . . Pruvot (29).

St. Vaast $\quad . \quad$. $\quad . \quad$. . Grube (14).

\section{†HaRmothö reticulata, Claparède.}

de St.-Joseph doubtfully refers a mutilated specimen taken near Dinard to this species.

Pruvot (29) records it from the Fucus zone of tidal waters, the zostera banks on a sandy bottom, stones covered with Cystoseira to the sandy gravel of his laminarian zone.

McIntosh (19) considers that this species is in all probability identical with Evarne impar.

\section{LocaLities.}

Dinard (Cézembre) . Dredging . . . de St.-Joseph (31).

Côtes de Bretagne . $\quad$. . . . Pruvot (29). 


\section{† HarmothoË torquata, Claparède.}

This species, which closely resembles $H$. spinifera of Ehlers, is an inhabitant of the Fucus zone of tidal waters, and is recorded by Pruvot (25) from the coasts of Brittany. It is introduced here on his authority.

\section{†HaRmothö̈ Sarniensis, Lankester.}

This species is recorded by Prof. Ray Lankester from Guernsey and Herm, where it appears to have been very abundant under stones near low-water mark.

According to Lankester it appears to replace $H$. imbricata, which it resembles very closely in other respects than the number of the elytra.

It is not noticed by McIntosh in his recent Monograph (20).

LocaLITIES.

Guernsey and Herm . Lankester (17).

*Eunoa nodosa, M. Sars.

This fine species is only occasionally found, and the only locality in the neighbourhood of Plymouth is the Eddystone Grounds.

\section{Eddystone Grounds . XVIII. . . Stones . [Weldon]. Allen (1). \\ * Evarne impar, Johnston.}

A very common tidal and deep-water species. McIntosh (20) states that it occurs under stones between tidemarks, in the crevices of tangle roots, and in the cavities of shells, both univalve and bivalve. This accords completely with my own experience in this neighbourhood, throughout which it appears to be pretty generally distributed. de St.-Joseph (32) describes the variety Pagenstecheri from St. Lunaire.

Pruvot (29) records it from his laminarian zone with a gravelly bottom, and also from the fine sand of the coastal region.

Plymouth: Area general.

\section{Localities.}

Eddystone Grounds VII. fine sand. XIV. fine gravel. XVIII. stones, Allen (1), T. V. H.

Salcombe . . Coralline zone . . . Parfitt (28).

Salcombe . . . . . T. V. H.

Torbay, Anstey's Cove . . . . Gosse (10).

Herm, Channel Islands Between tidemarks . . McIntosh (20).

Wimereux . . . . . . Darboux (8).

Dinard (rare), Isle de Rochefort, Saint Jacut de St.-Joseph (31).

Portel, Côtes du

Boulonnais . Under stones between tidemarks A. Malaquin (21).

Baas, Côtes du

Boulonnais . . Sand bank, dredgings . A. Malaquin (21).

St. Lunaire, Côtes de France . de St.-Joseph (32).

St. Malo . . . . . . Grube (12).

Côtes de Bretagne . Laminarian and coastal zones . Pruvot (29). 


\section{†Evarne pentact , Giard.}

Lives on the body of Cucumaria pentactes, with which holothurian it is commensal. It has not been recorded from this side the Channel.

Grisnez, Wimereux .

LOCALITY.

* Lagisca floccosa, Savigny.

This is one of the commonest of the local species, and may best be described as having a general distribution throughout the local area. It occurs between tidemarks to deep water, and under the synonym of L. propinqua it is recorded from the sand and gravel of the Eddystone Grounds.

Plymouth: Area general.

\section{Localities.}

Eddystone Grounds . Fine sand, coarse gravel with sand or mud, fine gravel, shellgravel, stones . . . Allen (1).

South Devon . . . . . . Johnston (16).

Wimereux . . . . . Darboux (8).

* Lagisca extenuata, Grube.

Not uncommon. It occurs most frequently under the laminarian roots on the Breakwater, and more rarely on the Eddystone Grounds, among the Polyzoa and Chotopterus tubes.

McIntosh (20) records it from the tube of a Eunice, and free on muddy sand; while Pruvot (29) gives its habitat as the Fucus zone down to the base of the rocks covered with Laminaria, and with a somewhat variable bottom.

\section{Localities.}

Plymouth: Breakwater, Eddystone Grounds.

Roche Bernard, Roche

de Lineur, Côtes du

Boulonnais . .

Dredgings, especially at Platriers Malaquin (21).

Wimereux . . . . . Darboux (8).

Dinard . . . Dredgings . . . de St.-Joseph (31).

St. Vaast, St. Guénolé, Croisic, St. Jean de Luz de St.-Joseph (32).

Côtes de Bretagne . Littoral zone . . . Pruvot (29).

* Lagisca rarispina, Sars.

This species is not admitted by McIntosh in his "Monograph of the British Annelids," nor is it included amongst the synonyms.

It appears to me to be very closely related to $L$. floccosa, with which species I should probably have identified it, had not Prof. Weldon drawn my attention to it in dealing with the Polychætes from the 
Eddystone Grounds (1). Since then I have found it in some numbers from that area and from the adjacent Mewstone Grounds.

\section{Localitites.}

Plymouth: Eddystone Grounds, Mewstone Grounds. EddystoneGrounds(1)VII. Fine sand

- [Weldon]. Allen (1).

Wimereux Darboux (8).

Between Ridens and Vergoyer, Pierrettes, Côtes du Boulonnais

\section{†Scalisetosus communis, Delle Chiaje.}

Not yet recorded from the neighbourhood of Plymouth.

Hornell (15) states that this species has been found commensally on three different kinds of starfishes.

\section{LocaLities.}

Channel Islands

Côtes du Boulonnais

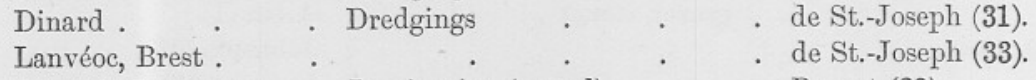

Tocanimes.

Côtes de Bretagne . Laminarian (gravel) . . Pruvot (29).

\section{* Scalisetosus assimilis, McIntosh.}

This species has recently been found upon the oral region of Echinus esculentus, Mr. R. A. Todd bringing it to my notice. I think $\mathrm{I}$ am justified in saying that it is not uncommon.

\section{LOCALITIES.}

Plymouth: Penlee, 3-5 miles S.W. (R. A. T.), Mewstone, Grounds.

Lanvéoc, Brest . . . . de St.-Joseph (33).

Côtes de Bretagne . Laminarian (gravel) . . Pruvot (29).

$\uparrow$ Scalisetosus echini, Giard.

Found by Giard as a commensal on the sea urchins Echinus sphcera and $E$. esculentus, in 30 fathoms.

\section{LOCALITy.}

Concarneau . . . . . . Giard (9).

\section{Polynoe scolopendrina, Savigny.}

McIntosh (20) gives the habitat of this species as the tubes of Polymnia (Terebella) nebulosa, between tidemarks, Herm, and between the chinks of rocks (gneiss), in muddy sand in the burrows of Lysidice. Other authors confirm the residence of this species more or less closely with Polymnia nebulosa, while de St.-Joseph (31) states that it is found on the shore under stones, where it constructs a tmbe of sand and bits of shell. 
Here at Plymouth it has only been found in two localities, viz. Millbay Channel and the Eddystone Grounds.

Specimens from the former locality make their appearance at rather long intervals, so that it cannot be called common, and it seems to frequent the chinks and crevices of the rocks which are found there, the depth being about 25 fathoms. Only a single specimen has been found on the Eddystone Grounds. This is considerably larger than the Millbay forms. It measures some $3 \frac{1}{2}$ inches in length, and the dorsum in the hinder part of the body bears three longitudinal rows of welldeveloped tubercles.

The Millbay specimens are small, barely two inches in length, and give one the idea of being disproportionately narrower. The dorsum is not tuberculated. In colour the specimens are approximately alike.

Plymouth : Millbay Channel.

Localities.

\begin{tabular}{|c|c|c|c|c|c|}
\hline Eddystone Grounds & . & . & . & . & . Allen (1). \\
\hline Falmouth $\quad$. & . & . & . & . & . Johnston (16). \\
\hline Channel Islands & . & . & . & . & McIntosh (20). \\
\hline Dinard . & . & Dredgings and & on sh & ore. & . de St.-Joseph (31). \\
\hline St. Malo & . & With terebellid & & . & $\begin{array}{l}\text { Audouin et } \\
\text { M.-Edwards (2). }\end{array}$ \\
\hline \multirow{3}{*}{$\begin{array}{l}\text { St. Malo, Roscoff } \\
\text { Côtes de Bretagne }\end{array}$} & . & . & . & . & Grube (12). \\
\hline & . & Himanthalia & and & laminarian & \\
\hline & & zones & . & . $\quad$. & Pruvot (29). \\
\hline
\end{tabular}

Not infrequently found on the shore under stones which rest on a basis, sometimes very scanty, of sandy mud, and occasionally in deep water. It cannot be called an abundant species. McIntosh (20) gives it its habitat under stones and in crevices, laminarian roots between tidemarks, and in the valves of old shells in deeper water.

Pruvot (29) gives the habitat of this worm on the coast of Brittany as the middle (Himanthalia) zone of tidal waters, and also his laminarian zone among the Laminaria, which accords with its distribution in the neighbourhood of Plymouth.

\section{LocaLITIES.}

Plymouth: Rocks below Laboratory, Rum Bay, Mewstone Grounds, off Stoke Point (R. A. T.), Wembury Bay (R. A. T.), Drake's Island (R. A. T.).

Eddystone Grounds IX. Coarse gravel, with sand or mud Allen (1).

Channel Islands

Dinard

At lowest tides in the holes bored in the mud by Nerine. . de St.-Joseph (31).

Roscoff .

Côtes de Bretagne . Himanthalia and laminarian zones . . . Pruvot (29). 


\section{* Acrolö̈ astericola, Delle Chiaje.}

Commensal in the ambulacral groove of Astropecten irregularis, this species is decidedly common, a very fair percentage of these echinoderms being accompanied by the worm. It is comparatively easy to find them; their colour betrays them, and they can be readily turned out of the ambulacral groove of the starfish, though it has hitherto proved impossible to preserve specimens entire.

Within an hour or two of capture the worm will voluntarily leave its host, and may be found wandering over the various animals with which it may be temporarily associated. This leads one to suppose that it is free during some portion of its existence, though I can find no evidence of its having been obtained in such a condition.

It occurs on several species of the genus Astropecten, Carus (5).

\section{Localities.}

Plymouth: Mewstone Grounds, off Stoke Point, S.W. ; Penlee Point, 5 miles S.E. ; Rame Head, 5 miles S.E. (R. A. T.).

Eddystone Grounds I.,
II., III.
Fine sand
. [T. V. H.] Allen (1).

\section{Lepidasthenia argus, $s p$. nov. Size to $8 \frac{1}{2}$ inches.}

General appearance. An elongated worm of upwards of 200 segments, coloured a warm buff, with a transverse band of dark brown between each segment. A red longitudinal line on ventral surface.

Elytra numerous, not very large comparatively, completely covering the sides of the body, but leaving a conspicuous median portion exposed; translucent, with a dark-coloured, more or less fan-shaped patch posterior to the centre; behind this a narrow crescentic band of opaque white.

\section{SPECIFIC CHARACTERS.}

Prostomium. Broad, red, with an antero-median depression dividing it into two lobes. Tentacles three, sub-equal, produced from the anterior margin of the prostomium. Median tentacle long, comparatively stout, distinctly swollen near the filiform tip, lateral tentacles more slender, the swelling indistinct. Tentacular cirri similar to the lateral tentacles. All these organs are smooth and possess a deeply pigmented band at the distal portion of the swelling, which is marked by a band of opaque white.

Eyes four, anterior pair wider apart and slightly larger than the posterior. Proboscis with $\frac{11}{11}$ papillæ and a small additional one on each side, a short distance from the extremity.

Elytra. On segments $1,3,4,6,8, \ldots 22,25,28$, et seq., to the end of the body. The first is subcircular, some few are uniform, but most 
are an irregular circle. Surface and margin quite smooth. Translucent, with faint granular pigment. Immediately behind the point of attachment is a brown-coloured patch with a sharp anterior border, fading gradually inwards and backwards. In the posterior elytra this pigmented area occupies most of the hinder portion of the elytron, and is fan-shaped. Near the posterior margin is a more or less conspicuous crescentic band of opaque white.

Parapodia. Notopodium reduced to a mere stump with a very few slender chatæ or none. Dorsal cirrus resembling tentacular cirri, and extending nearly to the extremity of the chætæ, except in a few of the anterior segments where it projects far beyond. Neuropodium well developed with numerous chætæ of a tolerably uniform character; the upper ones are longer and more slender. The spinulose rows are well developed; there are about forty of these on the more slender chætæ, and they become reduced to about twelve on the ventral side, the chætæ becoming shorter and stouter and finally more curved. The chætæ are bifid.

This remarkably fine species has recently been discovered at Salcombe by Mr. Todd, existing as a commensal in the tubes of Amphitrite Edwardsi.

It is one of the most brilliantly coloured of the Polynoids, and I am indebted to Mr. W. Garstang for the following description of the colour when alive :-

"General colour a warm buff, occasionally inclining to pink in some specimens. The intervals between the segments are marked by a conspicuous transverse bar of dark brown. In the anterior half of the body the bases of the cirrus-bearing parapodia are also coloured dorsally with a diffuse patch of the same pigment, which is scarcely perceptible on the elytron-bearing segments.

"In the posterior half of the body the pigment on the bases of the cirriferous parapodia fades completely away.

"Each elytron bears a dark brown patch immediately behind its point of attachment and spreading inwards towards the posterior border. The anterior margin of this pigmented area is sharp and well defined, but fades away distally. These pigmented areas lie on the lower surface of the elytra, but are clearly visible through their translucent integuments. In the anterior segments the spots are smaller and more strongly pronounced than in the posterior segments, where they gradually assume a broader and more fan-shaped outline. A more or less crescentic streak of opaque white near the posterior border of the elytra adds to the conspicuous character of these markings."

While this description was being prepared I was enabled to yisit Salcombe during the spring tides of October, when I secured a dozen 
specimens of the species. The colour varies a good deal while retaining all its essential characteristics, and in some individuals the dark brown appears to be more of a purple. I am inclined to believe that the natural colour is a purple rendered a rich brown by virtue of its intensity. Some of the individuals taken showed this very clearly, and in one case one half of the body was conspicuously lighter than the other.

The ventral surface is practically colourless except for a very strongly marked longitudinal line of bright red.

ElYTRA. In shape they are sub-circular, and some few reniform. From a certain variation in size it may be assumed that they are lost and replaced with comparative ease, though this is hardly borne out by the circumstances connected with their capture and preservation. The surface and margin are both smooth. Under the microscope a light brown pigment is visible over the entire surface of the elytron, and differs only in density from the visibly pigmented area. This pigment is deposited in small circular patches, each having a lighter spot in the centre. From the area of attachment the nerve runs in an arborescent manner over the entire elytron, the branching being very close and delicate.

Prostomium. Broad; the posterior portion is pigmented brown (in spirit). It consists of two ovoid lobes separated anteriorly by a median depression, which loses itself about half-way back. The tentacles are continuations forward of the prostomium, and their proportionate lengths seem to vary somewhat. The four eyes are postero-lateral in position, but not in contact with the margin; the anterior are slightly larger than the posterior.

Parapodia. Elongate, with the notopodium rudimentary.

First foot. The notopodium consists of a mere papilla, with a slender and tapering chæta. The neuropodium is well developed and subconical. It is provided with some thirty or more slender chætæ. The spinulose region of these is bent backwards and long. The apex is apparently truncate, but there are evidences of a minute cleft. The more ventral chætæ are shorter; the spinulose border is turned ventralwards. The ventral cirrus is very long.

The second foot is very similar; the ventral cirrus reaches beyond the neuropodium, and the dorsal cirrus extends very considerably further. The chætæ do not present any striking differences.

In the typical feet the notopodium increases in size for the stout part of the animal's body, and may carry four or five long, slender chætæ with no serrulations. In the neuropodium three groups of chætæ may be made out: an upper group, where the chætæ are few in number, long and slender, and with the spinulose region pro- 
portionally long; a median group, where the chætæ are by far the most numerous, and are stout, the spinulose region being distinctly shorter, and shortening as the chætæ pass to the ventral region, where it is shortest. The shafts of the most ventral chætæ are distinctly more slender, and form the third group, which is not always so sharply defined as the others.

The ventral cirrus is scarcely half the length of the neuropodium measured from the point of insertion of the cirrus.

With the doubtful exception of the first two feet, all the chætæ are bifid at the extremity, the only difference being the depth of the cleft.

The presence of chætæ in the notopodium is not a constant character. No definite statement can be made either as to the number of the segments or of the elytra, as these appear to be directly related to the size of the animal. The largest specimen I have seen measures $8 \frac{1}{2}$ inches in length with 67 elytra and 190 segments, and the smallest is $1 \frac{1}{2}$ inches long with 22 elytra. This last specimen, having been a month or so in spirit, is almost colourless. Another specimen, 2 inches long with 30 elytra, possesses the characteristic colour, but very feebly developed. In these two cases the elytra completely cover the body. A specimen, $5 \frac{3}{8}$ inches long with 54 elytra and 150 segments, has assumed the character and proportions described for the species. Specimens of intermediate size are necessary to trace the change in the proportions and colouration of the elytra.

The segmental papillæ are very prominent, more especially in the posterior part of the body, and the anus is provided with two short cirri.

The generic definition of Lepidasthenia given in the synopsis (p. 232) is a verbatim copy of Malmgren's original. This author appears to have had one or more specimens. Neither here nor in the original description of Grube's Polynoe elegans are any figures given, and nothing is said as to its habits. A figure, however, is given by Benham (3) in the Cambridge Natural History, and this unquestionably proves that the Salcombe species is distinct. This species does not accord with Malmgren's definition in the matter of the parapodia, but the difference does not justify the creation of a new genus, and the existing one must be amended in that particular.

\section{* Sthenelais BOA, Johnston.}

This is a common species, and occurs between tidemarks on a more or less sandy bottom, burrowing in the sand or under stones. It is also tolerably frequent in dredgings, especially where the bottom consists of stones and broken shells.

Pruvot (29) records it from sandy beaches near low tide, and from the zone of zostera banks. 
Möbius (27), referring to the North Sea, reports it generally on sandy ground, of varied character, frequently also with shells and shell fragments, sometimes on mud or on sand more or less mixed with mud.

\section{Localities.}

Plymouth: Drake's Island, Rum Bay, Bovisand Bay, off Rame Head, Mewstone Ground.

Salcombe

Zostera banks, and near low tide.

Exmouth

Tidemarks

Parfitt (28).

South Devon

Johnston (16).

Channel Islands, Herm

Wimereux, Plymouth .

Dinard .

McIntosh (20).

St. Malo, Roscoff . . . . . . Grube (12).

Darboux (8).

Côtes de Bretagne . . . . . . . . Pruvot (29),

St. Vaast

Grube (14).

\section{*Sthenelais limicola, Ehlers.}

The record of McIntosh cited below is all that I know of this species occurring in the neighbourhood of Plymouth. He notes it as an inhabitant of sandy ground in water of some depth, never between tidemarks.

\section{LOCALITIES.}

Cornwall, Polperro

. McIntosh (20).

\section{†Sthenelais minor, Pruvot and Racovitza.}

Taken once in a dredging between Ile Ronde and Lanvéoc Point, near Brest by de St.-Joseph. He expresses some doubt as to the identity of the species.

Pruvot (29) records it from the gravel at the base of his littoral zone.

\section{Localities.}

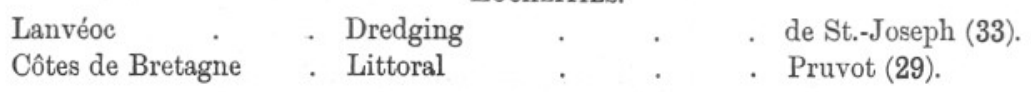

\section{†Sigalion Mathilde, $A u d$. et Edw.}

Recorded by McIntosh as a tidal form occurring under stones, and extending to deeper water on a more or less sandy ground: Pruvot (29) says sandy beach near low tide. Möbius (27) reports it from the North Sea on fine sand with shells.

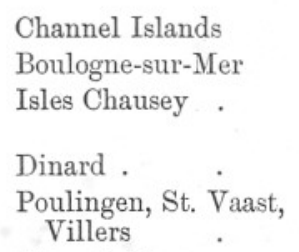

\section{Localities.}

. McIntosh (20). Darboux (8).

Audouin et M.-Edwards (2). de St.-Joseph (31). de St.-Joseph (32). Pruvot (29). 


\section{†Psammolyce Herminie, Aud. et $\boldsymbol{E} d w$.}

Pruvot (29) includes this species in his list of Polychætes from the coast of Brittany. He records it from the sandy beaches near low tide, and from the fine sand of the coastal region.

\section{Localities.}

Côtes de Bretagne . Pruvot (29).

\section{† Рноцоё minuta, Fabricius.}

This is a tidal as well as a deeper water species, and is found commonly under stones between tidemarks, and especially in pools (20). I have not seen it in the Plymouth neighbourhood.

\section{Localities.}

Channel Islands

Wimereux .

St. Malo

St. Vaast

- McIntosh (20).

. Darboux (8).

. Grube (12).

. Grube (14).

\section{†Pholö̈ synophthalmica, Claparède.}

A variety of this species, to which de St.-Joseph gives the qualification var. Dinardensis, is recorded as common in dredgings at all depths off Dinard.

Pruvot (29) records it from the base of his littoral zone with a gravelly bottom, to the fine sand of the coastal region.

\section{LocaLities.}

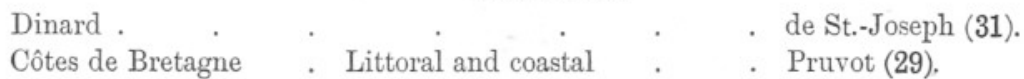

I have not sufficient information to assign to the following species their correct position.

\section{Polynoe lavis, Aud. et Edw.}

This species, according to Pruvot (29), is found on the sandy zostera banks of tidal waters, but may also be found in deeper water.

Audouin and Milne-Edwards, who first described this species, give no information as to the conditions under which it was found. The description has not that precision which is demanded by modern specialisation.

\section{Localities.}

Isles Chausey .

Litora Francogalliæ

Côtes de Bretagne

\begin{tabular}{|c|c|c|c|}
\hline - & • & • & Audouin and Edwards (2). \\
\hline$\cdot$ & & & . Carus (5). \\
\hline Zostera beds & & • & . Pruvot (29). \\
\hline
\end{tabular}




\section{Læenilla alba, Malmgren.}

Recorded by Grube from the French coast, but details of its capture are not given. The genus Lænilla of Malmgren has been modified and broken up, and this species would probably be included in the genus Malmgrenia of McIntosh.

\section{LOCALITY.}

St. Malo, Roscoff $\quad . \quad$. . . . Grube (12).

\section{Scalisetosus variegatum, $G r$. et $K r$.}

Included here on the authority of Pruvot (29), who includes it in his list of species occurring on the coast of Brittany. I have not met with any other allusion to the species.

\section{LoCALITY,}

Côtes de Bretagne . Cystoseira region . . . Pruvot (29). 


\section{NOTE ON PRUVOT'S BIOLOGICAL REGIONS.}

Pruvot (29) has dealt at some length with the fauna of the coast of Brittany and that of the Golfe du Lion in the Mediterranean.

In comparing the faunas of these two regions he shows how the life of the various species is intimately related to the conditions to which they are exposed, and the character of the surface on which they live.

I have here incorporated a summary of his observations in so far as they apply to the group under consideration and as regards the Channel fauna only.

It will be seen that his observations very accurately describe the distribution of Polychætes in the neighbourhood of Plymouth, but reference must be made to his work for one to realise its importance.

As his terminology differs from that in general use in this country it needs some explanation. He divides the depths of the sea into three regions: (1) Littoral, (2) Coastal, and (3) Abyssal, the last of which is not, of course, found in the Channel.

The littoral region is that in which the bottom is subjected to the influence of waves and superficial currents, and extends so far as to include the laminarian and a considerable portion of Forbes' coralline zone. The coastal region occupies the whole of the Channel below a depth of about 21 fathoms.

The following table will show better than mere description the subdivision and character of these regions and the three "facies" ascribed to each zone :-

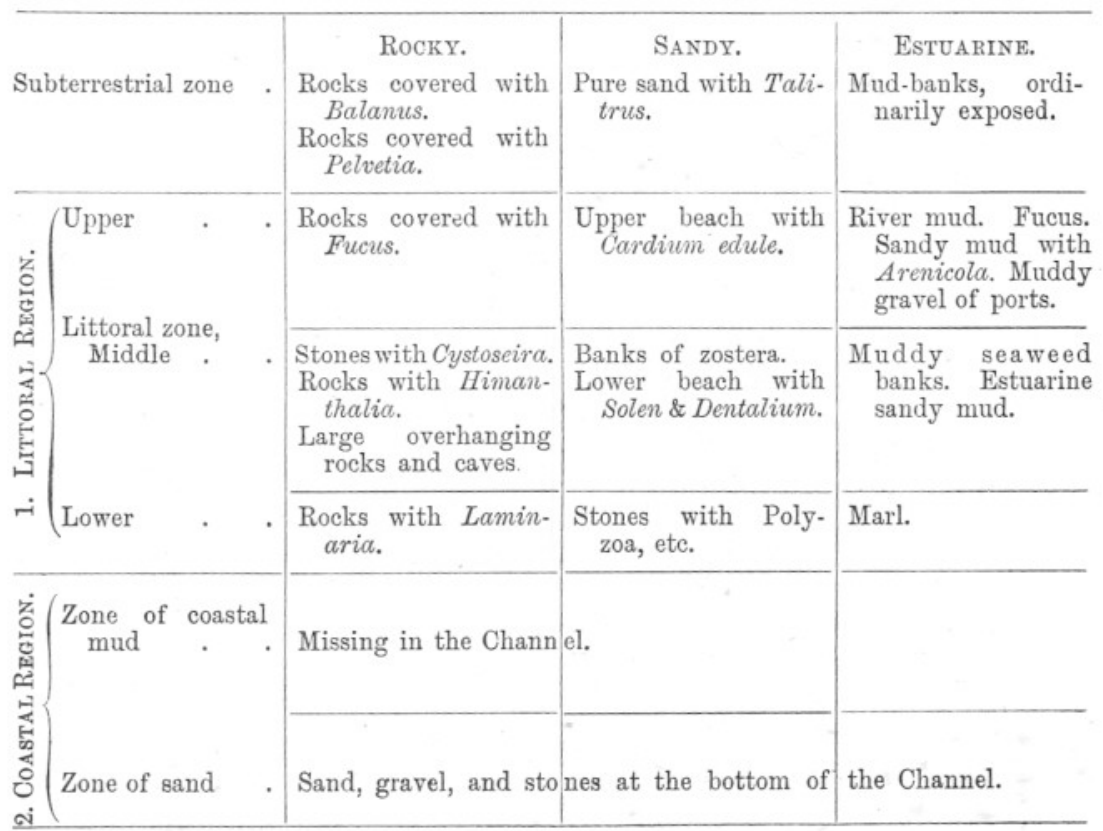




\section{REFERENCES.}

1. Allen.-On the Fauna and Bottom-deposits near the Thirty-fathom Line from the Eddystone Grounds to Start Point. Journ. Mar. Biol. Assoc., vol. v. 1899.

2. Audouin et Milne-Edwards.-Memoir pour servir à l'Histoire Naturelle de la France. Vol. ii. Annélides. Paris. 1834.

3. Benham, W. B.-Archiannelida, Polychæta, and Myzostomaria. Camb. Nat. Hist. vol. ii. 1896.

4. Bourne, A. G.-On certain points in the Anatomy of the Polynoina and on the Polynoë (Lepidonotus, Leach) clava of Montagu. Trans. Linn. Soc. Lond., ser. 2, Zool., vol. ii. 1883.

5. Carus, V.-Prodromus Faunæ Mediterraneæ. Stuttgart. 1885.

6. Claparède, E.-Les Annelides Chétopodes du Golfe du Naples. Genève et Bale. 1868.

7. Committee for the Exploration of the Marine Fauna of South Devon, Reports. Reports Brit. Assoc. 1865, 1867, 1869, 1872. Committee for Exploring the Marine Zoology of South Devon, Reports. Reports Brit. Assoc. 1879-80.

8. Darboux, J. G.-Recherches sur les Aphroditiens. Memoire 6. Trav. Inst. Zool. Univ. Montpellier et de la Stat. Marit de Cette. Lille. 1899.

9. Giard, A.-Sur quelques Polynoidiens. Bull. Scient. du Dep. du Nord, ser. 2, vol. ix. 1886.

10. Gosse, P. H.-A Naturalist's Rambles on the Devonshire Coast. London. 1853.

11. Grube, E.-Actinien Echinodermen und Wurmer des Mittelmeeres. Königsberg. 1840.

12. Grube, E.-Mittheilungen uber St. Malo and Roscoff und die dortige Meeres-, besonders die Annelidenfauna. Jahresb. schles. Gesellschaft für Vat. Cult. Breslau.

13. Grube, E.-Bemerkungen über die familie der Aphroditeen. Jahresb. der Schles. gesells. Breslau. 1875.

14. Grube, E.-Mittheilungen über St. Vaast-la-Hougue und seine Meeres-, besonders seine Annelidenfauna. Jahresb. schles. Gesellschaft für Vat. Cult. Breslau. 1869-72.

15. Hornell, J.-Report on the Polychætous Annelids of the L.M.B.C. Distriet. Proc. \& Trans. L'pool. Biol. Soc., vol. v. 1890-1.

16. Johnston, G.-A Catalogue of the British Non-parasitical Worms in the Collection of the British Museum. London. 1865.

17. Lankester, E. Ray.-On some New British Polynoina. Trans. Linn. Soc. Lond., vol, xxv. 1866.

18. McIntosh, W. C.-On the Annelida of the Porcupine Expeditions of 1869 and 1870. Part I. Euphrosynidæ to Sigalionidæ. Trans. Zool. Soc. Lond., vol. ix.

19. McIntosh, W. C.-On British Annelida. Part I. Euphrosynidæ to Sigalionidæ. Trans. Zool. Soc. Lond., vol. ix.

20. MeIntosh, W. C.-A Monograph of the British Annelids. Part II. Polychæta, Amphinomidæ to Sigalionidæ. Ray Society, London. 1900.

21. Malaquin, A.-Annélides Polychètes des côtes du Boulonnais. Revue Biol. du Nord de la France. Tome ii. 1889-90.

22. Malmgren, A. J.-Nordiska Hafs Annulater. Öfvers. K. vet. Akad. Forhand. Stockholm. 1865 . 
23. Malmgren, A. J.-Annulata Polychæta Spitsbergiæ, Grönlandiæ, Islandiæ et Scandinaviæ hactenus cognita. Öfvers. K. vet. Akad. Forhand. Stockholm. 1867.

24. Marenzeller, E. von.-Sudjapanische Anneliden. Math. Naturviss Akad. Wien. 1879.

25. Marenzeller, E. von -Zur Kenntniss der Adriatischen Anneliden. Sitzb. der K. K. Akad. zu wiss, zu Wien. 1874.

26. Möbius, K.-Die wirbellosen Thiere der Ostsee. Jahresbericht der Comm. z. wiss. Untersuchung der deutschen Meere, für 1871. Berlin. 1873.

27. Möbius, K.-Vermes. Jahresbericht der Comm. \%. wiss. Untersuch. der deutschen Meere. Berlin. 1875.

28. Parfitt, E.-A Catalogue of the Annelides of Devonshire, with Notes and Observations. Trans. Devon Assoc., vol, ii. 1867.

29. Pruvot, G.--Essai sur les Fonds et la Faune de la Manche Occidentale (Côtes de Bretagne) comparés a ceux du Golfe du Lion. Arch. Zool. Expér et Gen., ser. 3, vol. v. 1897 .

30. Pruvot, G., and E. G. Racovitza.-Materiaux pour la Faune des Annélides de Banyuls. Arch. Zool. Expér et Gen., ser. 3, vol. iii. 1895.

31. St.-Joseph, de.-Annélides Polychètes des côtes de Dinard. Parts II. and IV. Ann. des Sci. Nat., ser. 7, vols. v. and xx. 1888, 1895.

32. St.-Joseph - Les Annélides Polychætes des côtes de France. Ann. Sci. Nat., ser. 8 , vol. v. 1898 .

33. St.-Joseph.-Les Annelides Polychretes de la Rade de Brest et de Paimpol. Ann. Sci. Nat., ser. 8, vol. x. 1899. 